Document downloaded from:

http://hdl.handle.net/10251/52433

This paper must be cited as:

Fombuena Borrás, V.; Benardi, L.; Fenollar Gimeno, OA.; Boronat Vitoria, T.; Balart Gimeno, RA. (2014). Characterization of green composites from biobased epoxy matrices and bio-fillers derived from seashell wastes. Materials and Design. 57:168-174. doi:10.1016/j.matdes.2013.12.032.

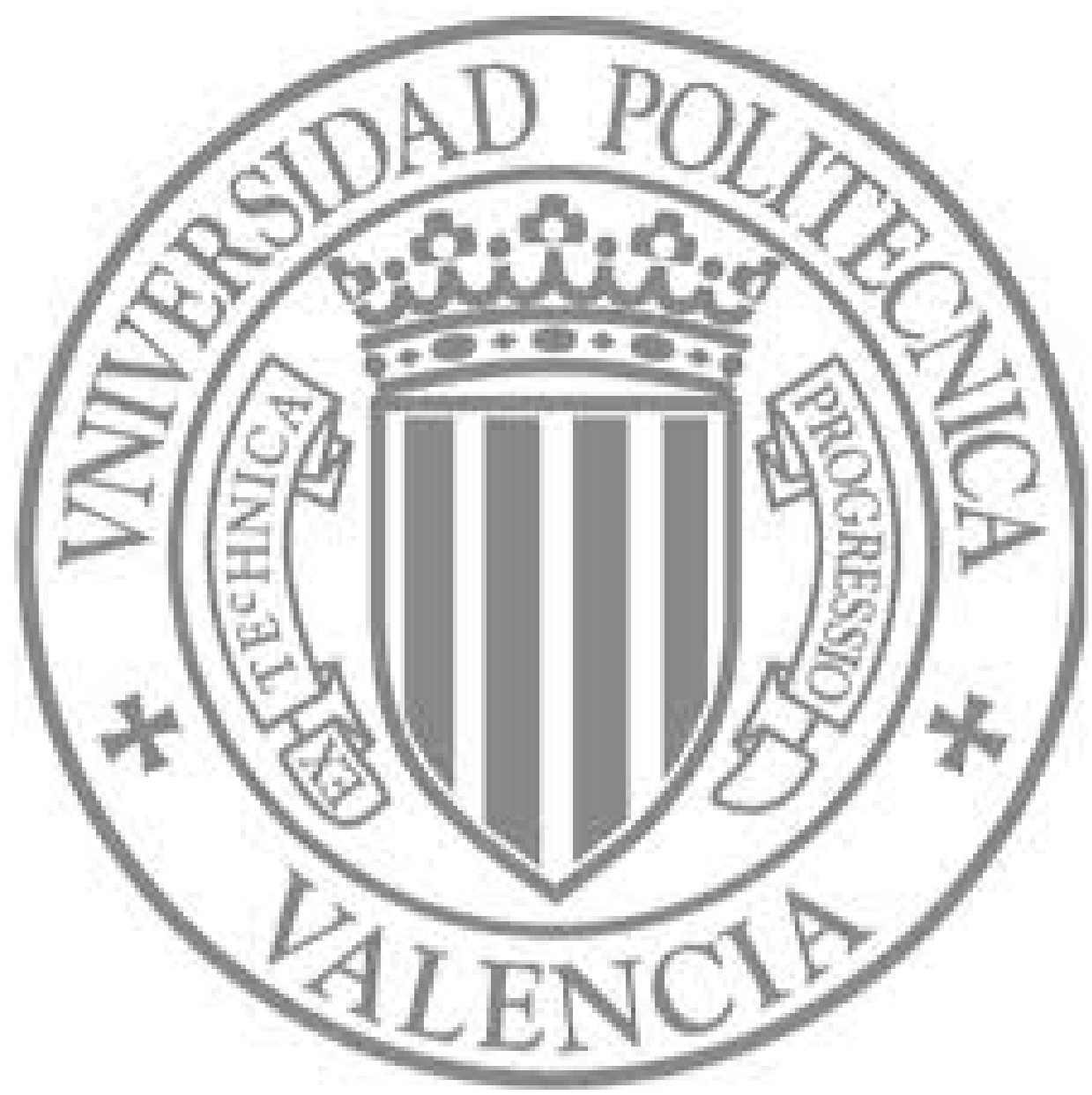

The final publication is available at

http://dx.doi.org/10.1016/j.matdes.2013.12.032

Copyright Elsevier 
Characterization of green composites from biobased epoxy matrices and bio-fillers derived from seashell wastes

\author{
V. Fombuena ${ }^{* 1}$, L. Bernardi ${ }^{2}$, O. Fenollar ${ }^{1}$, T. Boronat ${ }^{1}$, R.Balart $^{1}$ \\ ${ }^{1}$ Instituto de Tecnología de Materiales (ITM) \\ Universitat Politècnica de València (UPV) \\ Plaza Ferrandiz y Carbonell 1, 03801, Alcoy (Alicante), Spain \\ ${ }^{2}$ Centro de Tecnologia $(C T)$ \\ Universidade Federal de Santa Maria (UFSM) \\ Santa Maria - RS, 97105-900, Brasil
}

"Corresponding author: Vicent Fombuena

Telephone number/fax: 966528433

Email: vifombor@upv.es 


\title{
Characterization of green composites from biobased epoxy matrices and bio-fillers
} derived from seashell wastes

\author{
V. Fombuena ${ }^{*}$, L. Bernardi ${ }^{2}$, O. Fenollar ${ }^{1}$, T. Boronat ${ }^{1}$, R.Balart $^{1}$ \\ ${ }^{1}$ Instituto de Tecnología de Materiales (ITM) \\ Universitat Politècnica de València (UPV) \\ Plaza Ferrandiz y Carbonell 1, 03801, Alcoy (Alicante), Spain \\ ${ }^{2}$ Centro de Tecnologia $(C T)$ \\ Universidade Federal de Santa Maria (UFSM) \\ Santa Maria - RS, 97105-900, Brasil
}

\begin{abstract}
The seashells, a serious environmental hazard, are composed mainly by calcium carbonate, which can be used as filler in polymer matrix. The main objective of this work is the use of calcium carbonate from seashells as a bio-filler in combination with eco-friendly epoxy matrices thus leading to high renewable contents materials. Previously obtaining calcium carbonate, the seashells were washed and grinded. The powder obtained and the resin was characterized by DSC, TGA, X-ray diffraction (XRD), X-ray fluorescence spectroscopy (XRF), and rheology plate-plate. The results show that addition of $30 \mathrm{wt} \%$ of seashell bio-filler increase mechanical properties as flexural modulus (over 50\%) and hardness Shore D (over 6\%) and thermal properties as an increase around $13 \%$ in glass transitions temperature. The results show that the addition of calcium carbonate from seashells is an effective method to increase mechanical properties of bio-composite and to reduce the residue of seashells from industrial production.
\end{abstract}

Keywords: bio-polymers, epoxy resin, seashell, filler. 


\section{Introduction}

Excellent mechanical strength, electrical and chemical resistance, good thermal insulation and good adhesion to most fibers and fillers have made that epoxy resins are attracting as thermosetting resins. Nowadays it is possible to find epoxy resins in a wide variety of products: aerospace industry, automotive industry, adhesives, glues, paints, surface coatings, nautical materials, electrical and electronic components [1]. However the production of new polymer products focuses on new challenges: on one hand, the growing concern about the environment is leading to the development of new biobased and/or biodegradable materials. On the other hand, the competitiveness of markets requires products with best cost/performance balance. In this area is where the use of fillers is particularly interesting. The incorporation of fillers in a polymeric matrix is a faster and cost-effective way of achieving a desired set of properties [2-4].

One of the most commonly used inorganic filler is calcium carbonate $\left(\mathrm{CaCO}_{3}\right)$. This is due to its low cost, high capacity to improve mechanical properties such as stiffness and good particle dispersion in a polymeric matrix [5]. Calcium carbonate is the primary mineral content in the seashell of mollusks. Seashells of bivalves are an aquaculture by-product that due to the large consumption has become a serious solid waste problem. It is possible to use this waste as bio-filler for polymer matrices as it has a similar composition to conventional calcium carbonate. Canning industry generates great amounts of seashell wastes from different mollusks such as barnacles, mussels, clams, scallops, oysters, etc. In addition, presence of seashell wastes (mainly cockles, wedge-shells and other small bivalve shells) is generalized in the seashores (mainly after storms); in some cases, these waste seashells must be removed to provide clean beaches in order to obtain quality signs. 
Moreover, it is necessary to remark the difficulty to recycle thermosetting petroleum-based polymers, the strong dependence of finite fossil combustible and the environmental and health problems which involve the extraction, refinement, transport and storage of petroleum. For these reasons, a growing effort has emerged on the research and development of thermosetting materials from renewable resources with similar properties to conventional epoxy, unsaturated polyester and phenolic resins. One of the most promising materials are those derived from vegetable oils. Epoxidation of different vegetable oils leads to epoxidized vegetable oils (EVOs) with attraction properties from both economic and technical points of view. Different epoxidized vegetable oils (mainly epoxidized linseed oil-ELO and epoxidized soybean oil-ESBO due to their low cost) have been successfully used as thermosetting epoxy resins as coatings and polymer matrices with a wide variety of reinforcements [6-10]. Also, different products derived from the cashew nut shell liquid (CNSL) industry are attracting as biobased phenolic resins $[11,12]$ and some advances in biobased unsaturated polyester resins have been done by using biobased polyols and other components $[13,14]$

The main aim of this work was to develop a green composite from a commercial epoxy resin with more than $50 \%$ of percentage of biomass carbon content and bio-fillers derived from seashell of different bivalve mollusks collected from the seashore. The composition of the bio-fillers from seashells was determined and the effect of surface modification by silane coupling agents to provide good chemical affinity towards epoxy resin was also evaluated. The effect of the bio-filler content was studied in terms of the mechanical and thermal properties.

\section{Experimental details}




\subsection{Materials and sample preparation}

The base epoxy resin was a biobased epoxy resin from Sicomin, commercial grade Greenpoxy 55 (viscosity $=3000 \mathrm{mPa} \mathrm{s}$ and density $=1.152 \mathrm{~g} \mathrm{~cm}^{-3}$ at $20{ }^{\circ} \mathrm{C}$ ) supplied by Resineco Green Composites (Montmeló, Barcelona, Spain). Greenpoxy 55 is an epoxy system with a single hardener (viscosity $=1700 \mathrm{mPa}$ s and density $=0.99 \mathrm{~g}$ $\mathrm{cm}^{-3}$ at $20^{\circ} \mathrm{C}$ ), in which, $55 \%$ of the carbon derives from plant sources. The hardener used is also formulated with a minimum biobased carbon content of $55 \%$. The resin to hardener weight ratio was 100:40.

Seashell from different mollusks (mainly from cockles, wedge-shells and other small bivalve shells) collected from the coast of Valencia (Spain), were washed with $4 \%$ sodium hydroxide solution for $24 \mathrm{~h}$ to remove impurities, fibers, sand residues, etc [15]. After this, seashells were dried at $100{ }^{\circ} \mathrm{C}$ and grinded using an ultra-centrifugal mill (Mill ZM 1000 supplied by Retsch Gmbh, Haan, Germany). This mill has a rotor diameter of $99 \mathrm{~mm}$ of stainless steel. The rotational speed used is $6000 \mathrm{rpm}$ and subsequently, samples was sieved with a maximum particle size of $250 \mu \mathrm{m}$.

The coupling agent used was (3-glycidyloxypropyl) trimethoxysilane and was obtained from Sigma Aldrich (Sigma Aldrich Spain, Madrid, Spain).

In a first stage, the bio-filler was subjected to a silane treatment to improve the chemical interaction between the bio-filler (non-polar nature) and the resin (highly polar). The solutions containing silanes were prepared as follows: 1 wt. $\%$ of silane was diluted in a water:ethanol (50-50 volume ratio) solution and the seashell particles were immersed in these solutions for 15 minutes and then were dried in oven at $40{ }^{\circ} \mathrm{C}$ for 24 h.

After this initial treatment, grinded seashell particles were added to liquid epoxy:hardener system with different percentages ranging from 10 to $40 \mathrm{wt} \%$. Then 
the homogenized mixture was placed in a PTFE mold designed with standardized cavities for mechanical characterization and was placed in an oven to crosslink the liquid resin. The samples were crosslinked for 45 minutes at $100{ }^{\circ} \mathrm{C}$. Although this biobased epoxy resin can cure at room temperature, it was selected a temperature of 100 ${ }^{\circ} \mathrm{C}$ to avoid particle precipitation.

\subsection{Epoxy resin characterization}

The curing properties of the biobased epoxy resin were studied by thermal analysis and plate-plate rheometry. The DSC equipment used was a DSC MettlerToledo DSC 821e ((Metler-Toledo S.A.E.,Barcelona, Spain). A small drop of the liquid mixture resin:hardener (100:40 wt. \%) with a weight of 5-8 $\mathrm{mg}$ was placed in an aluminum crucible and was subjected to a dynamic thermal program from 30 to $350{ }^{\circ} \mathrm{C}$ at a heating rate of $10{ }^{\circ} \mathrm{C} \min ^{-1}$ in a $\mathrm{N}_{2}$ atmosphere. In addition, the isothermal curing behavior of the biobased epoxy resin was followed with a plate-plate rheometer AR-G2 (TA Instruments, New Castle, EEUU). The analysis was conducted using a two parallel plates $(\mathrm{D}=25 \mathrm{~mm})$ configuration, and the system was subjected to a time sweep program. The temperature used was $100^{\circ} \mathrm{C}$ during 1 hour. The controlled variable was $\%$ strain 0.1 and the frequency was $1 \mathrm{~Hz}$.

\subsection{Characterization of seashell particles}

The crystal structure of seashell particles was determined by X-ray diffraction (XRD). The scans of the analysis were made from $2 \theta=10-90^{\circ}$. The XRD intensity of the bio-filler was collected from a Seifert JSO-DEBYEFLEX model 2002 diffractometer and uses $\mathrm{CuNi}_{\alpha}$ radiation at a voltage of $40 \mathrm{kV}$ and a filament current of $40 \mathrm{~mA}$. 
Chemical composition of seashell particles was obtained by X-ray fluorescence spectroscopy (XRF) (PHILIPS MAGIX PRO) equipped with a tube of rhodium and screen of beryllium. The samples were analyzed in their powder form with a rhodium target excited at $30 \mathrm{kV}$ and $150 \mathrm{~mA}$. The spectra were collected for $300 \mathrm{~s}$ without a filter using a collimator with the smallest aperture. The specimen chamber was flushed with helium gas during data collection. Thermogravimetric analysis (TGA) was carried out in a TGA/SDTA 851 (Mettler-Toledo Inc., Schwerzenbach, Switzerland) with a heating program from $30{ }^{\circ} \mathrm{C}$ to $1000{ }^{\circ} \mathrm{C}$ at a heating rate of $10{ }^{\circ} \mathrm{C} \mathrm{min}{ }^{-1}$ under nitrogen atmosphere of $66 \mathrm{ml} / \mathrm{min}$.

\subsection{Mechanical and thermal properties of epoxy-seashell composites}

Mechanical flexural properties were obtained in an electromechanical universal test machine (Elib 30, Ibertest S. A. E, Madrid, Spain) following the guidelines of ISO 178:2010 entitled Plastics. Determination of Flexural Properties [16]. At least five different specimens for each composition were tested and average values were calculated. Shore D hardness values of the materials were obtained in a Shore D hardness durometer model 676-D (J. Bot Instruments, Barcelona, Spain) according to ISO 868:2003 entitled Plasctics and Ebonite. Determination for indentation hardness by means of durometer (Shore Hardness) [17]. Charpy impact values were obtained using a Charpy impact pendulum from Metrotec (Metrotec S.A, San Sebastian, Spain) with an energy of $6 \mathrm{~J}$ according to ISO 179-1:2010 entitled Plastics. Determination of Charpy impact properties. Part 1: Non-instrumented impact test [18].

Dynamic mechanical analysis (DMA) in torsion mode ware carried out in an oscillatory rheometer equipped with an environmental test chamber (ETC) with a rectangular torsion clamp system for solid samples. Samples sizing 40x10x4 mm3 were 
subjected to a dynamic program of temperature ramp from $30^{\circ} \mathrm{C}$ to $170^{\circ} \mathrm{C}$ at a heating rate of $5{ }^{\circ} \mathrm{C} \cdot \mathrm{min}^{-1}$. with these conditions: \% strain of $0.02 \mathrm{~Hz}$ and frequency of $1 \mathrm{~Hz}$.

\subsection{Morphology of epoxy-seashell composites}

A scanning electron microscope Phenom (FEI Company, Eindhoven, The Netherlands) was used to observe the fractured surfaces from impact tests. Before observation, samples were sputter-coated with a gold-palladium alloy with a Sputter Coater EMITECH mod. SC7620 (Quorum Technologies Ltd, East Sussex, UK).

\section{Results and discussion}

\subsection{Curing behavior of the biobased epoxy resin}

The curing process of the biobased epoxy resin was studied by dynamic DSC, and the obtained curve is shown in Fig. 1. Although this epoxy can be crosslinked at room temperature (curing time of about $24 \mathrm{~h}$ ), the selected temperature for the curing process of epoxy-seashell composites is $100{ }^{\circ} \mathrm{C}$ which is near the temperature peak of the dynamic curve.

\section{Figure 1}

As shown in Fig. 1, the resin:hardener mixture displays a single exothermic reaction peak, which is attributed to the crosslinking reactions between the epoxy and the hardener. In this dynamic heating program, the reaction starts at a temperature of 65 ${ }^{\circ} \mathrm{C}$ and ends at about $140{ }^{\circ} \mathrm{C}$. The peak temperature, which indicates the maximum crosslinking rate temperature, is located at $106{ }^{\circ} \mathrm{C}$. Thus, with the purpose to optimize the curing process and its efficiency, the resin will be cured at $100{ }^{\circ} \mathrm{C}$, since it 
guarantees a high crosslinking rates, resulting in a low curing time and, therefore, seashell particle precipitation is avoided. Regarding the exothermicity $(\Delta H)$, the released heat is $291 \mathrm{~J} \mathrm{~g}^{-1}$. This value around $300 \mathrm{~J} \cdot \mathrm{g}-1$, is similar to that obtained with other high renewable content epoxy resin, and higher than any petroleum-base epoxy resins (close to $200 \mathrm{~J} \cdot \mathrm{g}-1$ ), indicating a faster process chain crosslinking [19].

It is important to reach the gel point $\left(t_{\text {gel }}\right)$ at lower times to avoid particle precipitation which could lead to phase separation and heterogeneous material. The gel time can be determined by using oscillatory rheometry in which, the evolution of the storage modulus $\left(G^{\prime}\right)$ and the loss modulus $\left(G^{\prime \prime}\right)$ are plotted in terms of time. The gel time can be estimated as the crossover point between the storage and the loss modulus which represents a phase angle of $45^{\circ}$. Fig. 2 shows the evolution of the storage modulus $\left(G^{\prime}\right)$, the loss modulus (G') and the phase angle $(\delta)$ as a function of time at a constant curing temperature of $100^{\circ} \mathrm{C}$. The crossover point between $\mathrm{G}^{\prime}$ and $\mathrm{G}$ ' $(\delta=45$ $\left.{ }^{\circ}\right)$ is around 150 seconds and this is positive to avoid particle precipitation as described before. In addition, it is possible to determine the minimum time to reach a fully cured material at this isothermal temperature since the storage modulus $\left(G^{\prime}\right)$ tends to stabilize when a fully crosslinked structure is obtained. The optimum curing time is close to 2025 min since the storage modulus tends to a constant value of $3.6 \mathrm{MPa}$ as observed in Fig. 2.

\section{Figure 2}

\subsection{Characterization of seashell grinded powder}

Table 1 shows the chemical composition of the seashell powder obtained by $\mathrm{X}$ ray fluorescence spectroscopy (XRF). The chemical analysis of the seashell powders 
has been conducted to estimate the mineral composition and establish the potential of seashell wastes as bio source of calcium carbonate. The results show that the seashell is mainly composed of calcium in the form of calcium oxide $(\mathrm{CaO})$ which represents more than 94 wt. \%. This indicates that seashell is an attracting bio source of high purity calcium carbonate which is in agreement with other studies [20, 21]. Some other oxides appear with lower percentages around $1 \%\left(\mathrm{SiO}_{2}, \mathrm{Na}_{2} \mathrm{O}\right.$ and $\left.\mathrm{TiO}_{2}\right)$ and the rest are presents in trace amounts (less than one percent). Oxides as the $\mathrm{Fe}_{2} \mathrm{O}_{3}$ which can influence the oxidation of the polymeric matrix appear in concentrations below to 0.5 wt. \% reducing the risk of this kind of oxidation [22].

\section{Table 1}

The crystal structure of the seashell powder can be observed by analyzing the results of X-ray diffraction (XRD) (Fig. 3). The main diffraction peaks of the crystalline structures in the seashell are located in the $25^{\circ}-55^{\circ}$ range. As we have previously seen in Table 1 , seashell is mainly composed of $\mathrm{CaCO}_{3}$. Calcium carbonate is characterized by three characteristic crystal phases: aragonite, calcite and vaterite, although this last crystal phase is not usual in the nature and is only found in synthetic materials [23, 24]. For this reason, aragonite and calcite crystal forms can be observed in the XRD diffraction pattern. As we can see in the Fig. 3, the main diffraction peaks in the $25^{\circ}-55^{\circ}$ range correspond to the aragonite crystal form although some typical diffraction peaks of the calcite crystal form can be detected but in less extent. One of the most representative peaks of the aragonite is located at $26^{\circ}$ and corresponds to (111) reflections from the aragonite crystal structure [25]. The presence of the other peaks with similar intensity is due to the fact that seashell powder is made from different 
species of bivalve mollusk $\left(33^{\circ}, 38^{\circ}\right.$ and $\left.46^{\circ}\right)$ [26]. On the other hand, as it is clearly observable in Fig. 3, the intensity of the peaks corresponding to the calcite crystal form is lower than the aragonite diffraction peaks thus indicating that the predominant crystal form of calcium carbonate in seashell is aragonite. The most representative peak of the calcite crystal form is located between $29-30^{\circ}$, and corresponds to (104) reflections. Therefore, XRD confirms that calcium carbonate in seashell is mainly in the form of aragonite crystals which is a high density and hardness material, and this makes it an ideal material to be used as biobased filler in polymer matrices [27].

\section{Figure 3}

Thermal degradation of the seashell powder was studied by thermogravymetric analysis (TGA). The evolution of the weight loss from $30^{\circ} \mathrm{C}$ to $1000{ }^{\circ} \mathrm{C}$ of the seashell is shown in Fig. 4.

\section{Figure 4}

The degradation process takes place in two different stages. The first step occurs at relative low temperatures with a very small weight loss around the $250{ }^{\circ} \mathrm{C}$ which is due to the degradation of the organic content of the seashell [15]. The organic component is close to 2.4 wt. $\%$ as calculated by a step analysis in the TG curve. The second degradation step occurs at higher temperatures and corresponds to the thermal decomposition of calcium carbonate which starts at about $700{ }^{\circ} \mathrm{C}$ with a maximum decomposition rate at $817^{\circ} \mathrm{C}$. The total weight loss in this second degradation step is close to 42 wt. \% which is in total agreement with the theoretical decomposition of 
calcium carbonate as indicated in eq. 1. Assuming that there are no impurities, the degradation of the $\mathrm{CaCO}_{3}$ leads to approximately 40 wt. $\%$ of $\mathrm{CaO}$ and a 60 wt. $\%$ of $\mathrm{CO}_{2}[21]$

$$
\mathrm{CaCO}_{3} \rightarrow \mathrm{CaO}+\mathrm{CO}_{2}
$$

The thermogravymetric analysis of the seashell powder shows great thermal stability so that it is possible to confirm the suitability of this waste as biobased filler for polymer composites.

In addition, the filler has been characterized by SEM analysis. Fig. 5 shows different images of the seashell powder without and with silane treatment. The silane treatment is not the best coupling agent for carbonates but it plays an important role in avoiding particle aggregation thus leading to optimum particle dispersion. The grinding process leads to particles with a wide size spectrum as observed in Fig. 5a (40-100 $\mu \mathrm{m})$. The silane treatment does not change in a great extent the surface morphology but enables good particle dispersion (Fig. 5b).

\section{Figure 5}

\subsection{Mechanical and thermal properties of epoxy-seashell composites}

Fig. 6 shows the flexural modulus obtained by flexural test of epoxy composites with different loads of seashell bio filler since ranging from $5 \mathrm{wt} . \%$ up to $40 \mathrm{wt}$. $\%$. The results obtained using the ISO 178:2010 [16] are compared with the unfilled sample.

\section{Figure 6}


As it can be observed in Fig. 6, the flexural modulus increases up to a maximum filler content of $30 \mathrm{wt}$. \%. The flexural modulus of the unfilled epoxy resin is close to 2.2 $\mathrm{GPa}$ and this value is increase up to values close to $3.3 \mathrm{GPa}$ for $30 \mathrm{wt}$. \% seashell waste content which represents a percentage increase of about $56 \%$ with regard to the unfilled material. It should be noted that a relatively low filler content of about $10 \mathrm{wt}$. $\%$ leads to a remarkable increase in flexural modulus $(25 \%)$. An addition of more than 30 wt. \% seashell filler causes a decrease in flexural modulus. This could be related to aggregate formation which leads to stress concentration phenomena.

The improvement on flexural modulus below $30 \mathrm{wt} . \%$ seashell waste filler is a direct consequence of the chain mobility restriction caused by intra- and intermolecular interactions between the polar groups of the epoxy resin and the organic component of the coupling agent. Although silanes are not the best solution for coupling carbonate fillers, their use is interesting as there is a wide variety of organic coupling functionalities such as epoxy, amine, mercaptanes, carboxylic acid, etc. which are highly reactive toward oxirane groups of the epoxy resin [28-30]. In this case, the use of a glycidyl silane is useful to promote good interactions with the epoxy matrix and moreover the treatment of the seashell powder improves the filler dispersion in the polymeric matrix $[31,32]$. A Homogeneous dispersion is obtained with a relatively low content of seashell waste bio-filler (less than $30 \mathrm{wt} . \%$ ), resulting in an overall enhancement of the mechanical properties. On the other hand, if the content filler content increases over $30 \mathrm{wt} . \%$, the dispersion is not so good and some aggregates can be formed thus leading to presence of stress concentrators and, as a consequence, mechanical properties decrease. 
In addition to mechanical flexural properties of epoxy-seashell composites, hardness and impact properties have been determined.

\section{Figure 7}

The shore D hardness of the unfilled epoxy resin, obtained following the ISO $868: 2003$ [17], is close to 76. A small addition of about 5 wt. \% leads to an increase in hardness of almost $6 \%$ and this percentage increase stabilizes at values of 85-86 for composites containing 30-40 wt. \% seashell waste. However, one of the main drawbacks of the addition of fillers in polymeric matrices is the decrease in toughness and flexural properties which is mainly due to the stress concentration effect of filler particles [33]. With regard to Charpy's impact test results obtained following the advice of ISO 179-1:2010 [18] a clear decrease in toughness is obtained for samples with different content of seashell filler. The only addition of 5 wt. 5 of seashell filler promotes a decrease in toughness of almost $84 \%$. The change in the impact energy is from $1.34 \mathrm{~J} \mathrm{~cm}^{-2}$ (unfilled material) up to $0.13 \mathrm{~J} \mathrm{~cm}^{-2}$ (for samples containing 20-30 wt. $\%$ seashell filler). It is important to remark that the decrease in impact absorbed energy is not progressive. We can observe a step from values close to $1.3 \mathrm{~J} \mathrm{~cm}^{-2}$ for the unfilled material to values close to $0.1 \mathrm{~J} \mathrm{~cm}^{-2}$ for all the compositions considered in this study thus indicating that presence or absence of filler leads to a clearly evident different behavior whilst the filler content is not a key parameter in reducing energy absorption during impact.

Dispersion and the interaction between the polymeric matrix and the seashell powder is one of the key factors which can influence the mechanical properties of composites. These can be examined by SEM analysis and compositional analysis by 
EDX. The overall dispersion can be studied by EDX analysis at low magnification as shown in Fig. 8. Distribution of calcium is representative for the overall dispersion of the seashell powder in the polymeric matrix. The compounding process with a twinscrew extruder plays a key role in achieving optimum particle dispersion. Good dispersion is needed to obtain balanced properties on composites. Fig. 8 shows the calcium profiles obtained by EDX analysis on SEM images. We can clearly observe the absence of calcium in the unfilled material (Fig. 8a and Fig. 8b). The addition of 5 wt. $\%$ calcium carbonate from seashell wastes can be detected by SEM-EDX as observed in Fig. 8c and Fig. 8d. Although some small aggregates can be detected, the general situation is a fairly good particle dispersion of calcium carbonate so that indicating good particle dispersion obtained after the extrusion and subsequent injection processes. The observation of the calcium profiles for samples containing 20 and $40 \mathrm{wt}$. \% seashell particles can be observed in Fig. 8f and Fig. 8h respectively. We can see increasing particle content but the most important thing is that quite good dispersion of calcium is achieved even for high filler contents so that indicating good particle dispersion.

\section{Figure 8}

The addition of calcium carbonate from seashell also leads to an increase in glass transition temperature $\left(T_{g}\right)$. The glass transition temperature was measured as the maximum of the $\tan \delta$ curve, which is associated with material relaxation. All epoxyseashell compositions exhibited $T_{g}$ values above room temperature as it is possible to observe in the Fig. 9. The unfilled material shows a well-defined peak at a temperature of $80.6{ }^{\circ} \mathrm{C}$. As the seashell powder content increases, two different effects can be observed. Firstly, we observe an increasing tendency in $T_{g}$ values as the seashell content 
increases. So that, $T_{g}$ is increased up to values of $91.3^{\circ} \mathrm{C}$ for epoxy-seashell composite with 30 wt. \% calcium carbonate which represents a percentage increase of about $13 \%$. Changes in $T_{g}$ are related to chain mobility; thus, an increase in $T_{g}$ involves chain mobility restrictions which could be caused by good matrix-particle interactions. The use of inorganic fillers has been extensively used to increase glass transition temperature in thermosetting matrices. Some authors have reported an attracting increase in $\mathrm{Tg}$ values by adding low amounts of nanoclays [34]. The relatively high surface area of nanoclays are responsible for a remarkable increase in $\mathrm{Tg}$ values with low filler amounts as described by other authors. In the present work, the use of calcium carbonate microparticles does not have the same effect for low filler amounts due to lower surface area (derived from particle size) and due to low compatibility of particles with the epoxy matrix even with titanate coupling agent, so that, the added particles mainly act as fillers with a short effect on net's chain mobility. Secondly, the damping factor decreases as the seashell content increases; this can be observed by a decrease in $\tan \delta$ height which is directly related to the dilution effect caused by the addition of calcium carbonate filler. On the other hand, the unfilled material shows a narrow tan $\delta$ peak while the filled composites clearly show a broad $\tan \delta$ peak which indicates that the relaxation process occurs slower due to matrix-particle interaction $[35,36]$.

\section{Figure 9}

\section{Conclusions.}

The present study has revealed that the calcium carbonate from seashell is an attractive bio-filler to be used in combination with eco-friendly epoxy matrices thus leading to high renewable content materials. The use of relatively low gel time epoxy 
resins is needed in order to avoid particle precipitation which leads to phase separation and, consequently, heterogeneous materials. The high thermal stability and the wide availability of seashell make it an ideal filler to reduce material costs and also increase the mechanical and thermal properties. The results show that addition of 30 wt. $\%$ of seashell bio-filler leads to an increase of over $50 \%$ in flexural modulus which can be attributable to quite good particle-matrix interaction due to previous silane coupling agent which also contributes to high dispersion levels of the seashell powder. Addition of calcium carbonate from seashell wastes also leads to an increase in glass transition temperature, $T_{g}$ (around $13 \%$ for $30 \mathrm{wt}$ \% filler content) thus leading to higher thermal stability materials. The addition of high purity calcium carbonate from seashell wastes can contribute to lower price of epoxy resins from renewable resources which are still higher in comparison to petroleum-based epoxy resins.

\section{Acknowledgements}

L. Bernardi would like to thank CNPq, Consejo Nacional de Desenvolvimiento Cientifico y Tecnologico - Brasil for financial support through a scholarship number: 


\section{REFERENCES}

[1] Mustata F, Tudorachi N, Rosu D. Thermal behavior of some organic/inorganic composites based on epoxy resin and calcium carbonate obtained from conch shell of Rapana thomasiana. Composites Part B-Engineering. 2012;43:702-10.

[2] Fraga F, Vazquez I, Rodriguez-Nunez E, Martinez-Ageitos JM, Miragaya J. Influence of the Filler $\mathrm{CaCO} 3$ on the Cure Kinetic of the Epoxy Network Diglycidyl Ether of Bisphenol a (BADGE $\mathrm{n}=0$ ) With Isophorone Diamine. Journal of Applied Polymer Science. 2009;114:3338-42.

[3] He HW, Li KX, Wang J, Sun GH, Li YQ, Wang JL. Study on thermal and mechanical properties of nano-calcium carbonate/epoxy composites. Materials \& Design. 2011;32:4521-7.

[4] Nakamura Y, Yamaguchi M, Okubo M, Matsumoto T. Effects of Particle-Size on Mechanical And Impact Properties of Epoxy-Resin Filled with Spherical Silica Journal of Applied Polymer Science. 1992;45:1281-9.

[5] Doufnoune R, Chebira F, Haddaoui N. Effect of Titanate Coupling Agent on the Mechanical Properties of Calcium Carbonate Filled Polypropylene. International Journal of Polymeric Materials. 2003;52:967-84.

[6] Akesson D, Skrifvars M, Walkenstrom P. Preparation of Thermoset Composites from Natural Fibres and Acrylate Modified Soybean Oil Resins. Journal of Applied Polymer Science. 2009;114:2502-8.

[7] Lincoln JD, Shapiro AA, Earthman JC, Saphores JDM, Ogunseitan OA. Design and evaluation of bioepoxy-flax composites for printed circuit boards. leee Transactions on Electronics Packaging Manufacturing. 2008;31:211-20.

[8] Retegi A, Algar I, Martin L, Altuna F, Stefani P, Zuluaga R, et al. Sustainable optically transparent composites based on epoxidized soy-bean oil (ESO) matrix and high contents of bacterial cellulose (BC). Cellulose. 2012;19:103-9.

[9] Samper MD, Fombuena V, Boronat T, Garcia-Sanoguera D, Balart R. Thermal and Mechanical Characterization of Epoxy Resins (ELO and ESO) Cured with Anhydrides. Journal of the American Oil Chemists Society. 2012;89:1521-8.

[10] Takahashi T, Hirayarna KI, Teramoto N, Shibata M. Biocomposites composed of epoxidized soybean oil cured with terpene-based acid anhydride and cellulose fibers. Journal of Applied Polymer Science. 2008;108:1596-602.

[11] Das KN, Das TK, Pal NC, Lenka S. Polymers from renewable resources: Studies on synthesis, characterization and thermal analysis of resins derived from cardanol based dyesformaldehyde-substituted aromatic compounds. Journal of Polymer Materials. 2002;19:361-4.

[12] Yadav R, Awasthi P, Srivastava D. Studies on Synthesis of Modified Epoxidized Novolac Resin from Renewable Resource Material for Application in Surface Coating. Journal of Applied Polymer Science. 2009;114:1471-84.

[13] Caillol S, Desroches M, Boutevin G, Loubat C, Auvergne R, Boutevin B. Synthesis of new polyester polyols from epoxidized vegetable oils and biobased acids. European Journal of Lipid Science and Technology. 2012;114:1447-59.

[14] Fang SW, De Caro P, Pennarun PY, Vaca-Garcia C, Thiebaud-Roux S. Synthesis and characterization of new polyesters based on renewable resources. Industrial Crops and Products. 2013;43:398-404.

[15] Li HY, Tan YQ, Zhang L, Zhang YX, Song YH, Ye Y, et al. Bio-filler from waste shellfish shell: Preparation, characterization, and its effect on the mechanical properties on polypropylene composites. Journal of Hazardous Materials. 2012;217:256-62.

[16] ISO. 178:2010 Plastics. Determination of Flexural Properties2010. p. 19.

[17] ISO. 868:2003 Plasctics and Ebonite. Determination fo indentation hardness by means of durometer (Shore Hardness): ISO; 1998.

[18] ISO. 179-1:2010 Plastics. Determination of Charpy impact properties - Part 1: Noninstrumented impact test: ISO; 2010. 
[19] Bertomeu D, Garcia-Sanoguera D, Fenollar O, Boronat T, Balart R. Use of eco-friendly epoxy resins from renewable resources as potential substitutes of petrochemical epoxy resins for ambient cured composites with flax reinforcements. Polymer Composites. 2012;33:683-92. [20] Malu SP, Ita BI, Edem CA, Ogri OR. Determination of the Glass Making Potentials of Seashells from Great Kwa River, South Eastern Nigeria. Asian Journal of Applied Sciences. 2011;4:801-14.

[21] Mustakimah M, Yusup S, Maitra S. Decomposition Study of Calcium Carbonate in Cockle Shell. Journal of Engineering Science and Technolog. 2012;7:1-10.

[22] Hamester MRR, Balzer PS, Becker D. Characterization of Calcium Carbonate Obtained from Oyster and Mussel Shells and Incorporation in Polypropylene. Materials Research-IberoAmerican Journal of Materials. 2012;15:204-8.

[23] de Leeuw NH, Parker SC. Surface structure and morphology of calcium carbonate polymorphs calcite, aragonite, and vaterite: An atomistic approach. Journal of Physical Chemistry B. 1998;102:2914-22.

[24] Hirajima T, Bissombolo A, Sasaki K, Takeucki M. Synthesis of aragonite crystals from pulverized scallop shells. Hong Kong: International Academic Publishers Ltd; 2005.

[25] Kwon HB, Lee CW, Jun BS, Yun JD, Weon SY, Koopman B. Recycling waste oyster shells for eutrophication control. Resources Conservation and Recycling. 2004;41:75-82.

[26] Supaphorn T, Kazushi Y, Wei Leong Y, Hamada H. Development of Cockleshell-Derived $\mathrm{CaCO} 3$ for Flame Retardancy of Recycled PET/Recycled PP Blend. Materials Sciences and Applications. 2011;2:59-69.

[27] Sasaki K, Yamashita T, Tsunekawa M. Synthesis of Aragonite from Calcined Scallop Shells at Ambient Temperatures and Their Morphological Characterization by FE-SEM. Journal of the Mining and Materials Processing Institute of Japan 2002;118:553-8.

[28] Fombuena V, Sánchez-Nácher L, Samper MD, Juárez D, Balart R. Study of the Properties of Thermoset Materials Derived from Epoxidized Soybean Oil and Protein Fillers. Journal of the American Oil Chemists' Society. 2012;90:449-57.

[29] Sue HJ, Wang S, Jane J. Morphology and Mechanical Behaviour of Engineering Soy Plastics. . Journal polymer. 1997;38:5035.

[30] Wang S, Sue HJ, Jane J. Effects of polyhydric alcohols on the mechanical properties of soy protein plastics. Journal of Macromolecular Science-Pure and Applied Chemistry. 1996;A33:557-69.

[31] Barus S, Zanetti M, Lazzari M, Costa L. Preparation of polymeric hybrid nanocomposites based on PE and nanosilica. Polymer. 2009;50:2595-600.

[32] Jose JP, Mhetar V, Culligan S, Thomas S. Cross Linked Polyethylene/TiO2 Nanocomposites: Morphology, Polymer/Filler Interaction, Mechanics and Thermal Properties. Science of Advanced Materials. 2013;5:385-97.

[33] Wang S, Sue HJ, Jane J. Effects of polyhydric alcohols on the mechanical properties of soy protein plastics. Journal of Macromolecular Science-Pure and Applied Chemistry. 1996;33:55769.

[34] Sanchez-Jimenez PE, Perez-Maqueda LA, Perejon A, Criado JM. Nanoclay Nucleation Effect in the Thermal Stabilization of a Polymer Nanocomposite: A Kinetic Mechanism Change. J Phys Chem C. 2012;116:11797-807.

[35] Gerbase AE, Petzhold CL, Costa APO. Dynamic mechanical and thermal behavior of epoxy resins based on soybean oil. Journal of the American Oil Chemists Society. 2002;79:797-802.

[36] Miyagawa H, Mohanty AK, Drzal LT, Misra M. Nanocomposites from biobased epoxy and single-wall carbon nanotubes: synthesis, and mechanical and thermophysical properties evaluation. Nanotechnology. 2005;16:118-24. 


\section{Figure legends}

Figure 1.- Dynamic DSC curve of the curing process of eco-friendly resin Greenpoxy®.

Figure 2.- Curing profile of eco-friendly Greenpoxy® resin at isothermal conditions $\left(100^{\circ} \mathrm{C}\right)$ by plate-plate rheometry.

Figure 3.- X-ray diffraction pattern of the seashell powder with aragonite and calcite contributions.

Figure 4.- Thermogravimetric (TGA) curve of the degradation process of seashell powder.

Figure 5.- SEM images of seashell powder (500x) a) without silane treatment and b) with silane treatment.

Figure 6.- Variation of the flexural modulus of epoxy-seashell powder composites in terms of the filler content.

Figure 7.- Variation of hardness and impact energy (Charpy) of epoxy-seashell powder composites in terms of the filler content.

Figure 8.- SEM and EDX calcium profile of epoxy-seashell composites with different filler content (wt. \%) a) 0, b) 5, c) 20 and d) 40.

Figure 9.- Evolution of $\tan (\delta)$ of epoxy-seashell powder composites in terms of the filler content obtained by DMA in torsion mode. 
Figure1

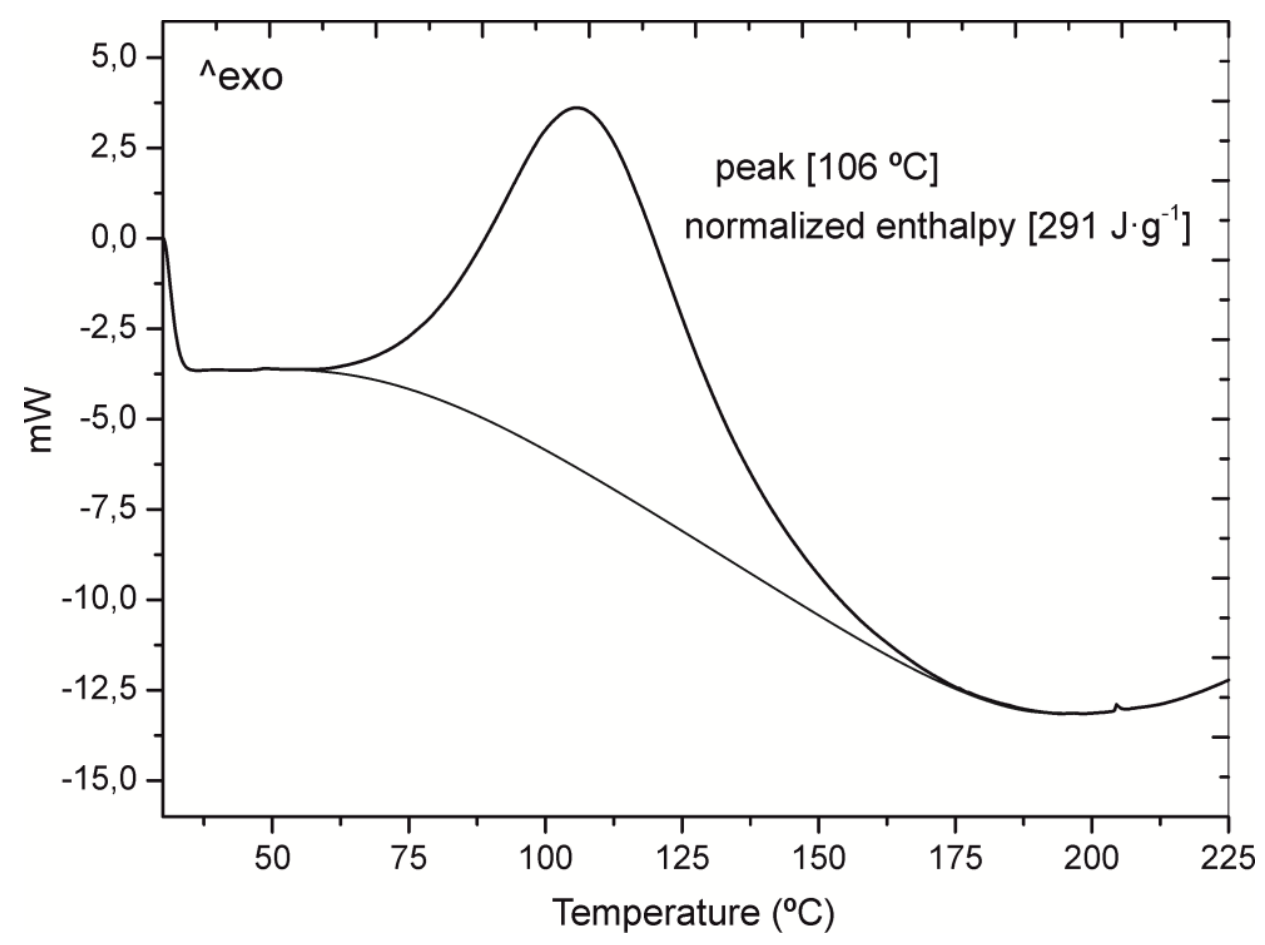


Figure 2

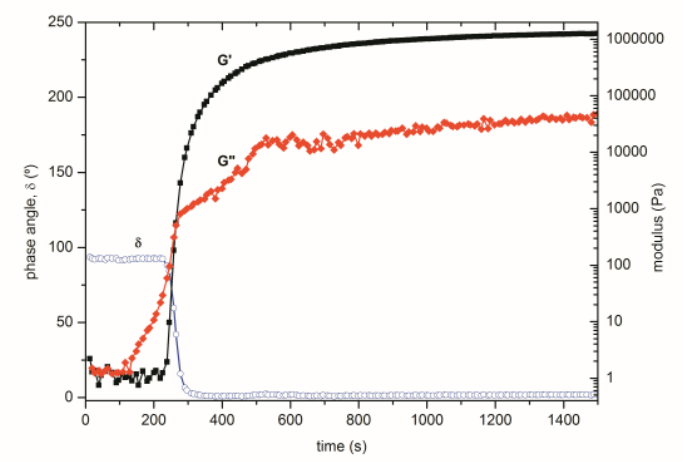


Figure 3

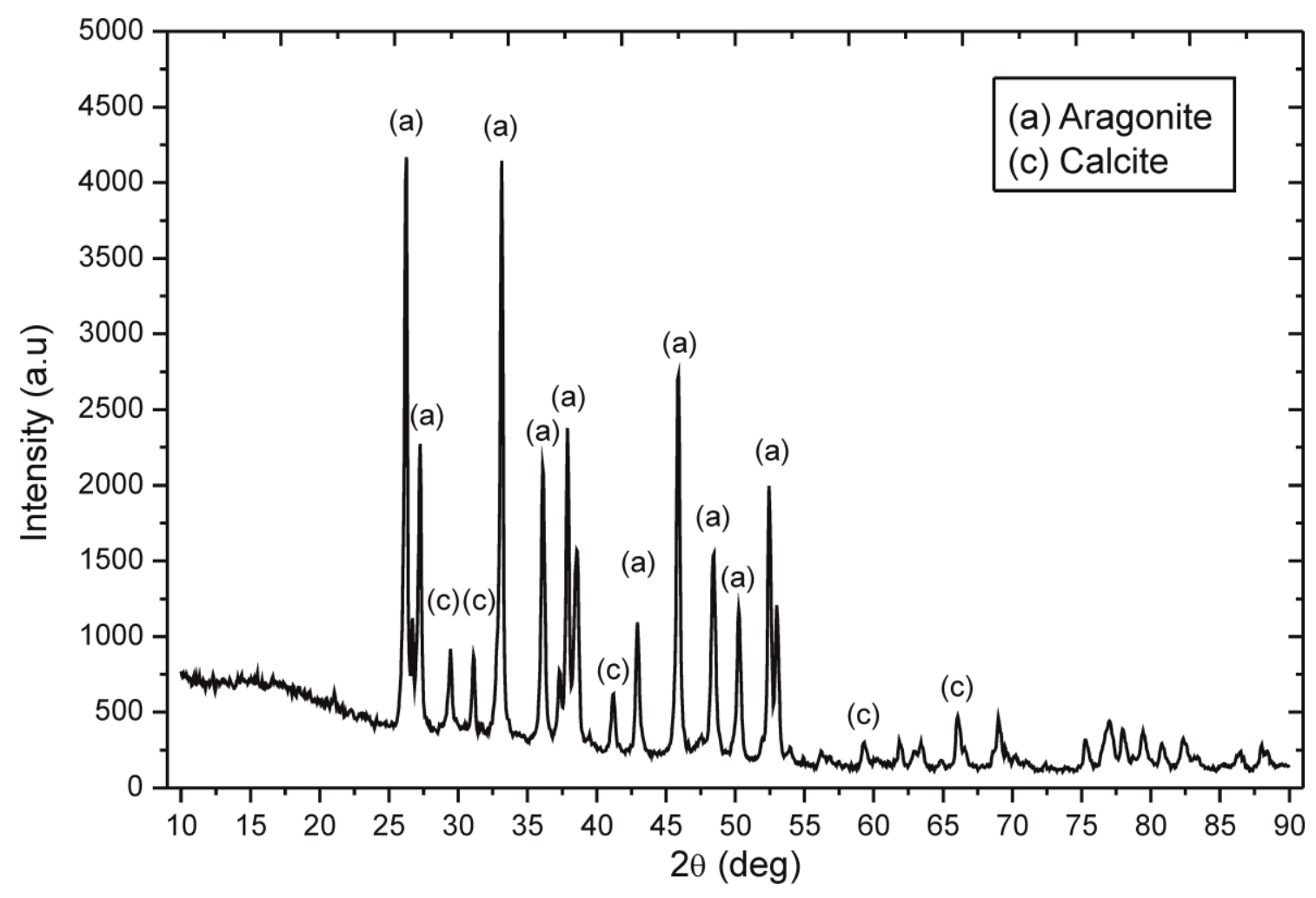


Figure 4

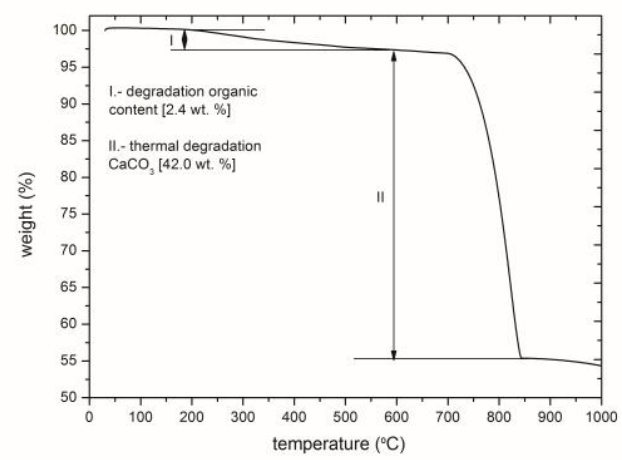


Figure 5
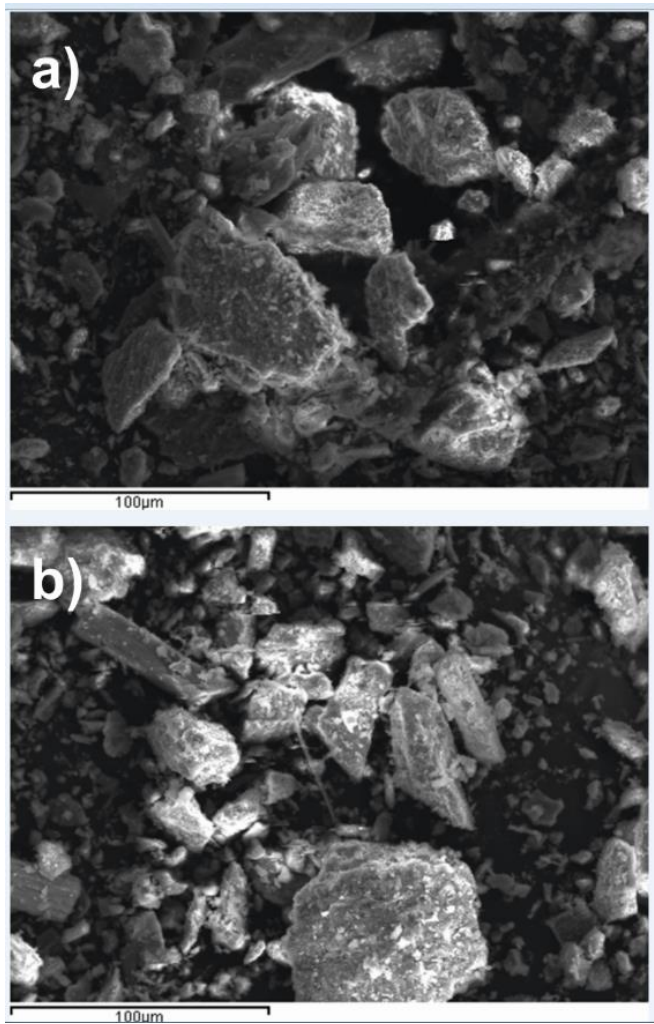
Figures 6

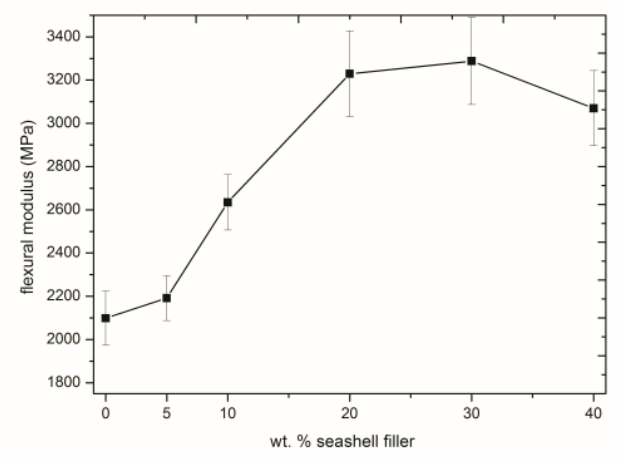


Figure 7

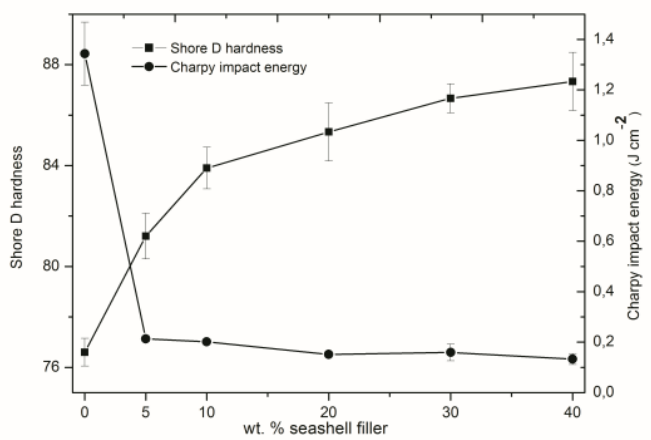


Figure 8
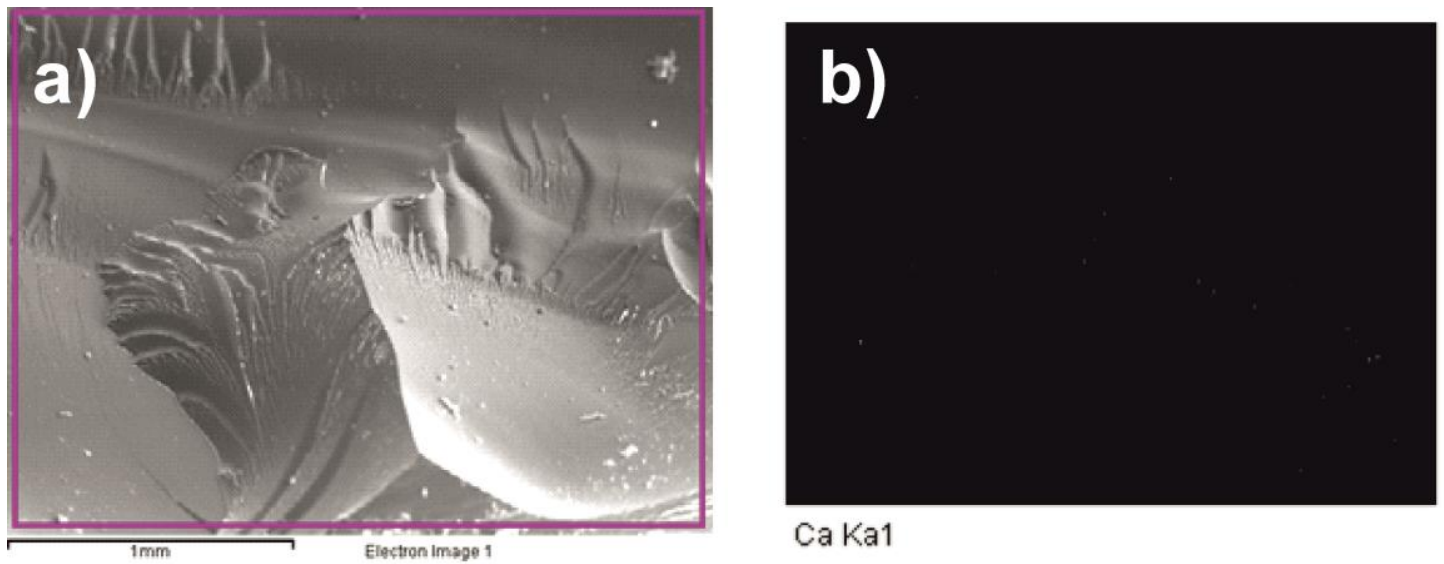

Ca Ka1
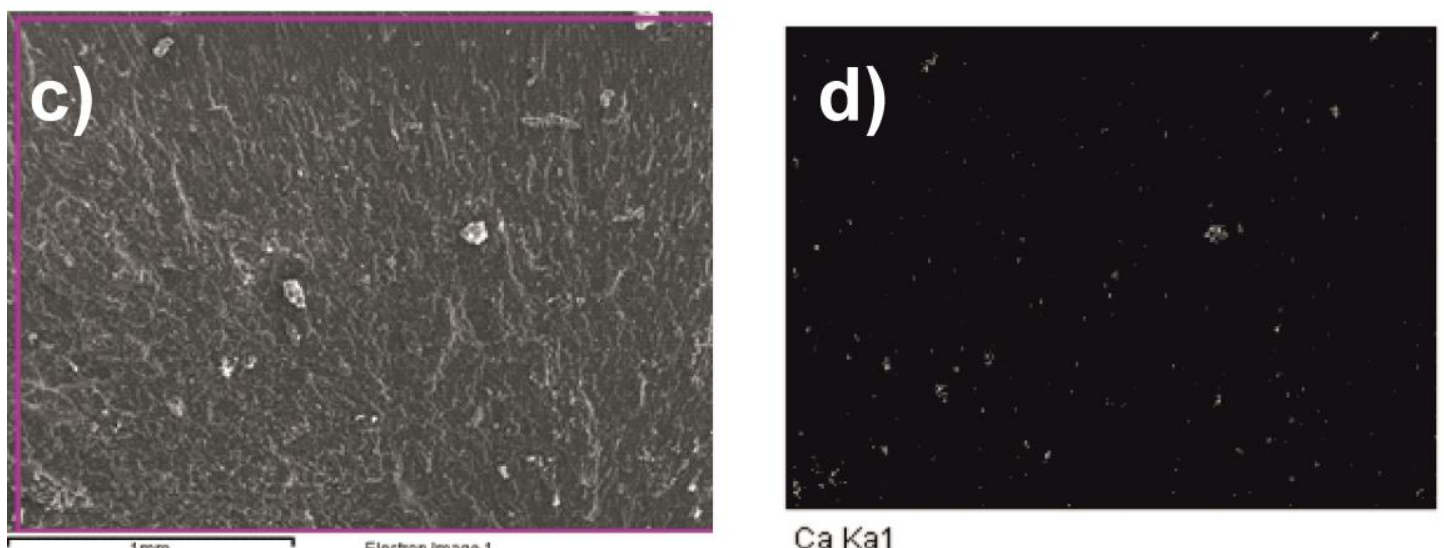

Ca Ka1
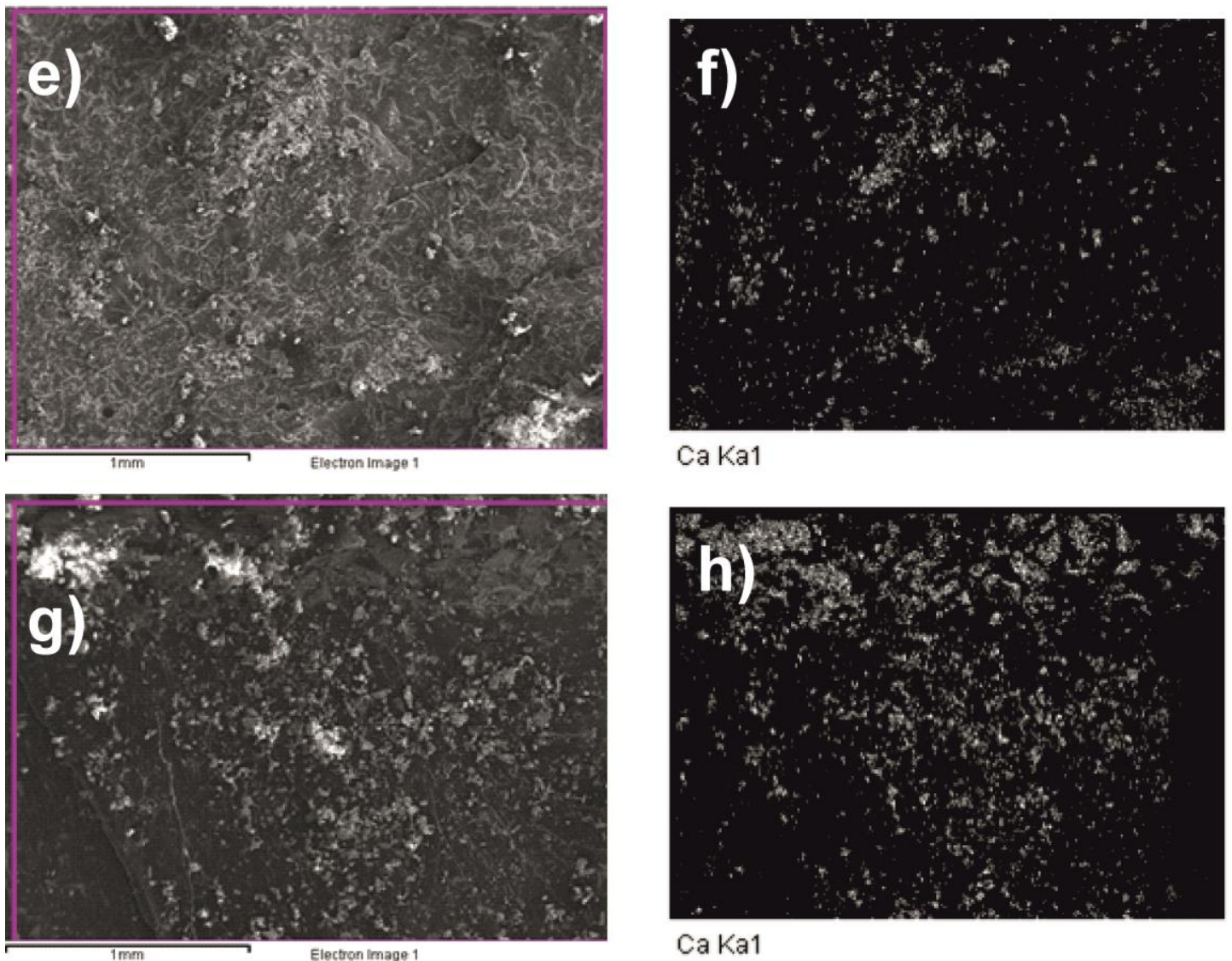

Ca Ka1 
Figure 9

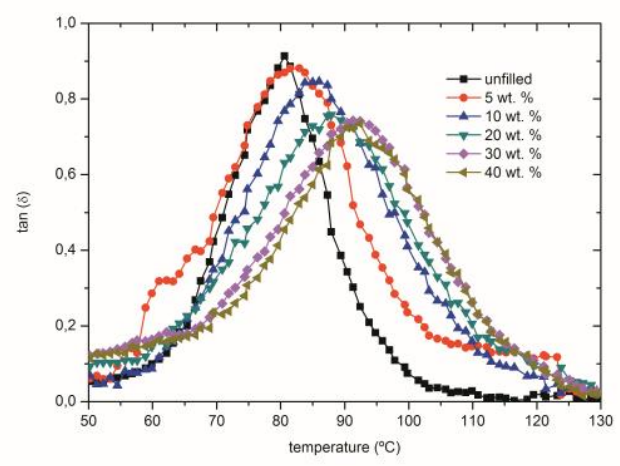


Table 1

\begin{tabular}{|c|c|}
\hline Oxide & wt. \% \\
\hline $\mathrm{CaO}$ & 94.1 \\
\hline $\mathrm{SiO}_{2}$ & 1.0 \\
\hline $\mathrm{Na}_{2} \mathrm{O}$ & 1.0 \\
\hline $\mathrm{TiO}_{2}$ & 1.0 \\
\hline $\mathrm{Fe}_{2} \mathrm{O}_{3}$ & 0.4 \\
\hline $\mathrm{SO}_{3}$ & 0.4 \\
\hline $\mathrm{SrO}$ & 0.3 \\
\hline $\mathrm{MgO}$ & 0.3 \\
\hline $\mathrm{Al}_{2} \mathrm{O}_{3}$ & 0.2 \\
\hline
\end{tabular}

